\title{
SIMULATION AND MODELLING SYSTEM FOR The Purposes of Crisis Management
}

\author{
Martin Ficek \& Dušan Vičar
}
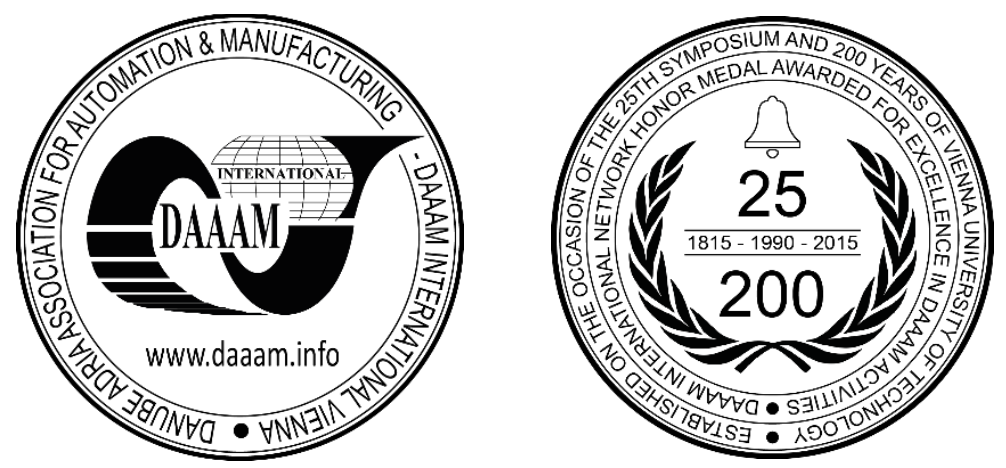

This Publication has to be referred as: Ficek, M[artin] \& Vicar, D[usanka] (2017). Simulation and Modelling System for the Purposes of Crisis Management, Proceedings of the 28th DAAAM International Symposium, pp.0974-0980, B. Katalinic (Ed.), Published by DAAAM International, ISBN 978-3-902734-11-2, ISSN 1726-9679, Vienna, Austria DOI: $10.2507 / 28$ th.daaam.proceedings. 135

\begin{abstract}
Hazardous chemical substances are used virtually every day. When these are stored or transported, extraordinary events occur from time to time, and as a consequence, health or lives of people within the reach of the accident or in the surroundings through which a hazardous cloud of this substance may spread are in danger. For a more efficient and easier operation of the emergency services and of the workers in crisis management, software products are used that model and simulate leakages of these substances and this way, they provide valuable information. This article compares the selected software and evaluates its efficiency.
\end{abstract}

Keywords: software; Aloha; crisis management; modelling; simulation

\section{Introduction}

The today's world depends on a whole number of chemicals and these substances have a wide use in industry. In many cases, these are hazardous chemical substances. Hazardous chemical substances have a number of pitfalls. In this article, we will deal with the issues of a leakage of a hazardous chemical substance. Leakages happen mostly during the transport or storing of a substance. For modelling and simulation of extraordinary events with hazardous substances, a number of programs are used. These programs can be used for management and for the corresponding company workers, as well as for workers of the crisis management and units of the emergency services. There, this program can relatively quickly provide basic necessary information to solve the extraordinary event at hand.

These issues are broad and appropriate attention is given to them practically around the whole world. An example can be the article called Crisis Management Modelling and Simulation Laboratory [1]. This article deals with, for example, the danger of a leakage of a chemical substance during transport that is carried out in a densely populated area and with the impacts of such leakage.

In their article, Bernatik, A. et al. [2] deal with the very necessary addition to the regular software (the abbreviation SW) products such as Terex or Aloha in the form of models of computational fluid dynamics or physics modelling in aerodynamic tunnels, and they provide data that they subsequently compare with the outputs of regular SW products. In a similar fashion, the article Application of Computational Fluid Dynamics for Manufactured Gas Dispersion Modelling and Leakage Consequence Analysis by Sun, H. et al. [3] deals with the computation of fluid dynamics. 
Since not only the transported substance has to be a hazardous substance, but also the fuel itself can be like, for example, the nowadays already relatively frequently used Liquefied Natural Gas (the abbreviation LNG), it is necessary to count even with these substances, and even in this case, it is possible to use appropriate SW products for the purposes of crisis management, as stated by the authors of the article called LNG as a potential alternative fuel - Safety and security of storage facilities. [4]

The article Using the SW modelling and simulating tools in transport of hazardous cargos by Ficek, M. et al. [5] is directly covers the comparison of two selected SW products. The article follows these publications and tries to further elaborate on them. The aim of this article is to provide background information for the evaluation of the selected software, both on the level of statistics, as well as based on a comparison with real-life situations and last but not least based on the SWOT analysis.

\section{Used tools and methods}

ALOHA - uses statistical mathematical models (SLAB and DEGEADIS). This software (there is an abbreviation in the article: SW) displays maximum concentrations and their reach. It does not display the development of substance leakage, but the overall maximum impacts. Modelling in the Aloha SW provides three options from the viewpoint of a leakage of hazardous substances and these are: gas leakage in the form of a cloud, whose output is only the final concentration (without relation to time). An instantaneous (one-time) leakage, which means diffusion of one gas or fumes and by dispersion with the wind - here, it's possible to get information about the time behaviour. The third type is an "accidental" leakage that is time-dependent, there is no specific statistical model and that's why the Aloha SW computes a series of five final durations in a steady state of concentrations, with the cloud not reacting with the environment being meant here. Every cloud contributes to the resulting concentration at any point and time. [material in German 15] Despite the fact that he Aloha SW does not display the course of the accident in time, it is possible to display the time behaviour of the concentration at a chosen point. [5, 6, 7]

The tool called Area Locations of Hazardous Atmospheres, abbreviated as ALOHA, created by the US Environmental Protection Agency in cooperation with the National Oceanic and Atmospheric Administration, (the United States of America) is a program designed for the modelling of leakages of hazardous chemical substances with leakage to the atmosphere. It has the advantage of a relatively large database of substances; its disadvantage is that it works only with the variant of non-reacting substances (it does not take into account reaction with the environment). It also does not take into account any other influences. An advantage is that it is possible to connect the program with measuring devices and to work with their data. The output is a figure of the threatened area (Threat Zone). However, these areas can be influenced by the setting of the level of the concern indicator (Level of Concentration - LOC). The result is tables and graphs of mathematical calculations that can be visualised using the MARLPLOT tool, which is, along with ALOHA, part of the package of the CAMEO Software Suite, or using the Arc Tool extension at Arc View and Arcmap. [5, 6, 7]

Key characteristics: Non-commercial, shareware, great range and possibilities of numerical results and calculations, calculation of the speed of substances leakage with a prognosis for the future, cooperation with other CAMEO tools. [5, $6,7]$

Works with the following input data:

- Data about the leaked substance

- Data about the state of the atmosphere

- Data about the source of the leakage

- Direct source (type of the leakage - immediate or continuous, amount of the substance leaked or the speed of the leakage, height of the source above the ground)

- Puddle (surface of the spilled liquid, volume, weight or depth of the puddle, type of the foundation, temperature of the foundation, temperature of the leaked substance)

- Container (type of the container and its orientation - spherical, cylindrical, vertical or horizontal, diameter, height or volume of the container, state of the substance in the container, temperature of the stored substance, weight or volume of the substance, type and dimensions of the escape hatch - rectangular or circular, type of leakage - punctured hole in the shell or short piping, height of the opening above the bottom, type of foundation and its temperature, presence of a leakage sump, or its dimensions) [5, 6, 7]

The output data are:

- Maximum speed of the leakage, in liquids, this concerns the speed of evaporation, not the speed of the leakage.

- Maximum average of the leakage speed per minute (average speed of the leakage during the minimum time of $1 \mathrm{~min}$ ), in liquids, this again concerns the speed of evaporation. In devices that work under pressure, overestimation may occur by influence of a swift initial leakage.

- The total amount of the leaked substance during the period of maximum 1 hour.

- Maximum reach of the threat zone, where the concentration will reach the entered value.

- Maximum concentration of the leaked substance in a randomly entered place.

- Maximum dose in the selected place that the organism took in after the leakage in the course of 1 hour. [5, 6, 7] 


\section{Emergency Response Planning Guidelines (ERPGs)}

"ERPGs are exposure guidelines designed to anticipate health effects from exposure to certain airborne chemical concentrations." [8]

"ERPGs estimate the concentrations at which most people will begin to experience health effects if they are exposed to a hazardous airborne chemical for 1 hour. (Sensitive members of the public-such as old, sick, or very young peoplearen't covered by these guidelines and they may experience adverse effects at concentrations below the ERPG values.)

A chemical may have up to three ERPG values, each of which corresponds to a specific tier of health effects. ” [8]

The three ERPG tiers are defined as follows:

"ERPG-3 is the maximum airborne concentration below which nearly all individuals could be exposed for up to 1 hour without experiencing or developing life-threatening health effects. " [8]

"ERPG-2 is the maximum airborne concentration below which nearly all individuals could be exposed for up to 1 hour without experiencing or developing irreversible or other serious health effects or symptoms which could impair an individual's ability to take protective action." [8]

"ERPG-1 is the maximum airborne concentration below which nearly all individuals could be exposed for up to 1 hour without experiencing more than mild, transient adverse health effects or without perceiving a clearly defined objectionable odor." [8]

\section{$\underline{\text { Paired two-sample t-test }}$}

In this article, the paired two sample t-test will be used for the statistical evaluation.

This test compares data that form "paired variance rows", that means that they come from entities that have been subjected to two measuring. So we are conducting 2 measuring in a single selection set: 1 . measuring before the application of the experimental intervention (in our case real measured data / data acquired by CEI calculation), 2. after the application of the experimental intervention (simulated data). The values acquired in this way from pairs and in testing represent both the control and experimental group of the compared data. [9]

In the test, we are building on the differences of the measured pair values in the compared variance rows. We are testing a hypothesis that states that the median values of the measurement before the experiment and after it are equal (or: the difference of the median values of the pair measuring is zero). [9]

First, we calculate the differences of the pair values in the selection set ( $\mathrm{n}$ - number of pairs) and from the established differences, we calculate the arithmetical average X and the standard deviation "s" (or dispersion s2). [9]

Then we calculate the test criterion (statistics) t:

$$
t=\frac{|X|}{\sqrt{\frac{s^{2}}{n}}}
$$

To find the table critical value, it is necessary to determine the number of degrees of discretion of the selection set: $\mathrm{v}=\mathrm{n}-1$ and to choose the significance level $\alpha$. [9]

We compare the resulting statistics $t$ with the table critical value $t 1-\alpha / 2(v)$, where $v=n-1$ and $\alpha$ is chosen to be 0.05 . [9]

If $\mathrm{t} \leq \mathrm{t} 1-\alpha / 2(\mathrm{v})$, then the statistically insignificant difference is $\mu 1$ and $\mu 2$ with a chosen $\alpha$. (We are not disapproving the null hypothesis $\mathrm{H} 0$ that is that the median value of the measuring before the experiment does not differ from the median value of the measuring after the experiment). [9]

If $\mathrm{t}>\mathrm{t} 1-\alpha / 2(\mathrm{v})$, then the statistically significant difference is $\mu 1$ and $\mu 2(\alpha=0.05)$ (We are disapproving the null hypothesis $\mathrm{H} 0$ that is that the median value of the measuring before the experiment differs from the median value of the measuring after the experiment). [9] 


\section{Results}

Many pieces of information are necessary for the individual situations, however, these are not completely relevant for the purpose of this article and by reason of conciseness, only the most important will be included here and these are: the amount and the type of the leaking substance. In the following table, you can see both the acquired real values and the values (from a threat zone corresponding with ERPG-3) acquired using simulation in the appropriate SW.

\begin{tabular}{|c|c|c|c|c|}
\hline Situation & \multicolumn{2}{|c|}{ Data } & REAL (km) & $\begin{array}{c}\text { ALOHA } \\
(\mathbf{k m})\end{array}$ \\
\hline \multirow[b]{2}{*}{1.} & Substance & Chlorine & \multirow[b]{2}{*}{$2.0 / 0$} & \multirow[b]{2}{*}{7.2} \\
\hline & $\begin{array}{l}\text { Amt. of } \\
\text { Sub. (kg) }\end{array}$ & 188 & & \\
\hline \multirow[b]{2}{*}{2.} & Substance & Ammonia & \multirow[b]{2}{*}{0.220} & \multirow[b]{2}{*}{2.8} \\
\hline & $\begin{array}{c}\text { Amt. of } \\
\text { Sub. }(\mathrm{kg})\end{array}$ & 86 & & \\
\hline \multirow{2}{*}{3.} & Substance & $\begin{array}{c}\text { Hydrogen } \\
\text { Chloride }\end{array}$ & \multirow{2}{*}{0.50} & \multirow{2}{*}{0.390} \\
\hline & $\begin{array}{c}\text { Amt. of } \\
\text { Sub. (kg) }\end{array}$ & 49 & & \\
\hline \multirow{2}{*}{4.} & Substance & $\begin{array}{l}\text { Methyl } \\
\text { Chloride }\end{array}$ & \multirow{2}{*}{0.15} & \multirow{2}{*}{0.056} \\
\hline & $\begin{array}{c}\text { Amt. of } \\
\text { Sub. (kg) }\end{array}$ & 112 & & \\
\hline \multirow[b]{2}{*}{5.} & Substance & Acetaldehyde & \multirow[b]{2}{*}{0.17} & \multirow[b]{2}{*}{1.2} \\
\hline & $\begin{array}{c}\text { Amt. of } \\
\text { Sub. }(\mathrm{kg})\end{array}$ & 70 & & \\
\hline \multirow[b]{2}{*}{6.} & Substance & Benzene & \multirow[b]{2}{*}{0.23} & \multirow[b]{2}{*}{0.6} \\
\hline & $\begin{array}{c}\text { Amt. of } \\
\text { Sub. }(\mathrm{kg})\end{array}$ & 127 & & \\
\hline \multirow{2}{*}{7.} & Substance & $\begin{array}{l}\text { Hydrogen } \\
\text { Fluoride }\end{array}$ & \multirow{2}{*}{0.8} & \multirow{2}{*}{3.99} \\
\hline & $\begin{array}{c}\text { Amt. of } \\
\text { Sub. (kg) }\end{array}$ & 76 & & \\
\hline \multirow[b]{2}{*}{8.} & Substance & Ammonia & \multirow[b]{2}{*}{0.16} & \multirow[b]{2}{*}{2.7} \\
\hline & $\begin{array}{c}\text { Amt. of } \\
\text { Sub. (kg) }\end{array}$ & 46 & & \\
\hline \multirow[b]{2}{*}{9.} & Substance & Formaldehyde & \multirow[b]{2}{*}{0.78} & \multirow[b]{2}{*}{4.96} \\
\hline & $\begin{array}{c}\text { Amt. of } \\
\text { Sub. }(\mathrm{kg})\end{array}$ & 58 & & \\
\hline \multirow[b]{2}{*}{10.} & Substance & Chlorine & \multirow[b]{2}{*}{1.4} & \multirow[b]{2}{*}{7.6} \\
\hline & $\begin{array}{c}\text { Amt. of } \\
\text { Sub. (kg) }\end{array}$ & 93 & & \\
\hline
\end{tabular}

Table 1. Resulting values

After the data from the table (real and ALOHA) have been applied on the statistical part mentioned above, we get the resulting decision on the hypothesis $\mathrm{H} 0$. $\mathrm{HO}$ is a hypothesis that states that the median values are equal.

If we follow the procedure, we will find, that the arithmetical average of the difference between the actual measured reach of the substance and the simulated reach in the Aloha SW is -2.5086 , the number of measuring is 10 and the dispersion s 2 of the difference between the actual measured reach of the substance and the simulated reach in the Aloha $\mathrm{SW}$ is 2.224222621 .

After substitution into the formula:

$$
t=\frac{|X|}{\sqrt{\frac{s^{2}}{n}}}
$$

The resulting value is $t=5.319151$

The table critical value $t 1-\alpha / 2(v)$ where $v=n-1$ and $\alpha$ is chosen as 0.05 is 3.25 . 
The conclusion is that $t>t 1-\alpha / 2(v)$. We have a statistically significant difference here. We're disapproving the null hypothesis $\mathrm{H} 0$, that means that the median value of the real measured values differs from the median value of the simulated values acquired using the Aloha SW.

$\underline{\text { SWOT-based analysis }}$

The selected SW is evaluated using the SWOT analysis, which evaluates strengths, weaknesses, opportunities and threats. This analysis will also be quantified. It is necessary to realise, that the analysis will be related to the findings that have been stated above. That means that it will be influenced in comparison to a real situation.

\begin{tabular}{|c|c|c|}
\hline SWOT - Aloha & Helpful & Harmful \\
\hline Internal origin & $\begin{array}{c}\text { Strengths: } \\
\text { Models allow for a greater } \\
\text { possibility of simulations. } \\
\text { The option to select many } \\
\text { simulations provides complexity. } \\
\text { Possibility to expand the database } \\
\text { of hazardous substances. }\end{array}$ & $\begin{array}{l}\text { Weaknesses: } \\
\text { The results are significantly } \\
\text { overrated and they absolutely don't } \\
\text { correspond with reality. }\end{array}$ \\
\hline External origin & $\begin{array}{l}\text { Opportunities: } \\
\text { Specification of the resulting } \\
\text { simulations. } \\
\text { Simplification of operation with the } \\
\text { possibility to use the SW out in the } \\
\text { field. }\end{array}$ & $\begin{array}{l}\text { Threats: } \\
\text { If we're planning measures } \\
\text { according to the results of this SW, } \\
\text { we will use unnecessarily many } \\
\text { powers and means and we will } \\
\text { disrupt operation in an area that is } \\
\text { unnecessarily large. }\end{array}$ \\
\hline
\end{tabular}

Table 2. SWOT analysis from the Aloha SW

\begin{tabular}{|c|c|c|c|}
\hline Strengths & Evaluation & Weight & Resulting value \\
\hline $\begin{array}{c}\text { Models allow for a greater } \\
\text { possibility of simulations. }\end{array}$ & 4 & 0.3 & 1.2 \\
\hline $\begin{array}{c}\text { The possibility to select many } \\
\text { simulations provides } \\
\text { complexity. }\end{array}$ & 4 & 0.3 & 1.2 \\
\hline $\begin{array}{c}\text { Possibility to expand the } \\
\text { database of hazardous } \\
\text { substances. }\end{array}$ & 5 & 0.4 & 2 \\
\hline Total & Evaluation & Weight & Resulting value \\
\hline Weaknesses & -4 & 1 & -4 \\
\hline $\begin{array}{c}\text { The results are significantly } \\
\text { overrated and they absolutely } \\
\text { don't correspond with reality. }\end{array}$ & & & -4 \\
\hline Total & & & \\
\hline
\end{tabular}

\begin{tabular}{|c|c|c|c|}
\hline Opportunities & Evaluation & Weight & Resulting value \\
\hline $\begin{array}{c}\text { Specification of the resulting } \\
\text { simulations. }\end{array}$ & 5 & 0.5 & 2.5 \\
\hline $\begin{array}{c}\text { Simplification of operation } \\
\text { with the possibility to use the } \\
\text { SW out in the field. }\end{array}$ & 5 & 0.5 & 2.5 \\
\hline Total & Evaluation & Weight & Resulting value \\
\hline Threats & -4.5 & 1 & \\
\hline $\begin{array}{c}\text { If we're planning measures } \\
\text { according to the results of this } \\
\text { SW, we will use unnecessarily } \\
\text { many powers and meansand } \\
\text { we will disrupt operation in an } \\
\text { area that is unnecessarily large. }\end{array}$ & & & -4.5 \\
\hline Total & & & -4.5 \\
\hline
\end{tabular}

Table 3. Quantification of SWOT analysis of the Aloha SW. 
- $\quad$ Internal value $=$ strengths + weaknesses $=4.4-4=0.4$

- $\quad$ External value $=$ opportunities + threats $=5-4.5=0.5$

- $\quad$ Resulting value $=$ Internal value + External value $=0.4+0.5=0.9$

The resulting number is not staggeringly high by any means, nevertheless, it is still positive and therefore, the SW can be considered a success. The fact that the results of the simulations are significantly overrated is at fault. If the information from the simulations would be used in a crisis management (there is an abbreviation in the article: CM), the measures would take place on an unnecessarily large area and they would restrict normal operation in this area, not speaking of a significantly increased price of the intervention. Moreover, the SW is relatively complicated and it can be used out in the field only with greater difficulties, which is another disadvantage. The Aloha Software is designed rather for more complicated simulations and its task is to show the worst possible scenario.

\section{Conclusion}

There is a great number of software products available that create models and simulations of hazardous substances leakage. Where is their place in the area of crisis management? Definitely in crisis management and preparation for emergencies, nevertheless, also in the course of a reaction to an emergency. These areas seem to be similar, but upon a closer look, you will be able to find that each of them requires a specific SW. For example, if we're using SW in crisis management, we need to know the worst possible scenario and conduct complicated simulations. To do that, we need a SW that provides a wide spectrum of settings (types of leakages, types of containers, types of buildings, weather settings, inversion settings, etc.) - during planning, the worker has enough time for a complicated simulation and settings. By contrast, in an intervention, it is necessary to react as quickly as possible and there's no time to enter much data. Here, the SW that needs only several basic information in a simple interface is used, which will provide relatively precise and reliable information necessary for an intervention.

In this article, we tested the Aloha SW. SW Aloha is more suitable for more complex situations, when it its necessary to know the worst possible variant even at a price of a relatively great distortion of the threatened areas. Both the finding from the statistical comparison and the SWOT analysis correspond to this.

It is necessary to realise, that a program is only an aid. The main responsibility remains on the crisis workers and authorised persons. They must treat the results from a SW critically and confront them with their experience and findings from practice. Only a decision taken based on such information is usually of quality and beneficial.

The future in this field will focus on making the results more precise and creating an interface that will be simple and that will provide immediately available information for an intervention, but at the same time, that will be possible to expand and used for more complicated and complex situations. Also, it will be more common for SW products to be connected to sensors and actuators in the future and security will significantly increase. This situation can be used as an example: A hazardous substance will start leaking from the piping, the sensor detects and localises the leakage. Actuators close the given part of the building and they prevent further leakage. Automatically, the relevant workers are alarmed, along with the appropriate organs of the CM and the emergency services and a warning is issued for the surroundings. Such systems are only in development, but this is exactly the way that you should take.

\section{Acknowledgments}

This work was supported by the European Regional Development Fund under the project CEBIA-Tech Instrumentation No. CZ.1.05/2.1.00/19.0376 and also by the Internal Grant Agency of Tomas Bata University under the project No. IGA/FAI/2017/015

\section{References}

[1] Björnham, O. (2013), Crisis Management Modeling and Simulation Laboratory. In: . pg. 759. DOI: 10.1007/97894-007-5577-2_129. Also available at: http://link.springer.com/10.1007/978-94-007-5577-2_129

[2] Bernatik, A. (2008). Modelling accidental repases of dangerous Gates into the Loir troposphere from mobile sources. In: Process Safety and Environmental Protection. 86(3), pgs. 198-207. DOI: 10.1016/j.psep.2007.12.002. ISSN 09575820. Also available at: http://linkinghub.elsevier.com/retrieve/pii/S0957582008000037

[3] Sun, H. ; Ning, P. \& Tang, L. (2010). Application of Computational Fluid Dynamics for Manufactured Gas Dispersion Modeling and Leakage Consequence Analysis. In: 7th International Symposium on Safety Science and Technology (ISSST). Hangzhou, PEOPLES R CHINA. ISBN 978-7-03-029089-2.

[4] Bernatik, A. (2011). LNG as a potential alternative fuel - Safety and security of storage facilities. In: Journal of Loss Prevention in the Process Industries. 24(1), pgs. 19-24. DOI: 10.1016/j.jlp.2010.08.003. ISSN 09504230. Also available at: http://linkinghub.elsevier.com/retrieve/pii/S0950423010001014 
[5] Ficek, M.; Vičar, D.; Rak, J. \& Svoboda, P. (2016) Using the SW modeling and simulating tools in transport of hazardous cargos, at the conference. In: TRANSPORT MEANS 2016. Juodkrante, Lithuania: Kaunas university of technology, 2016, pgs. 862-865. ISSN 2351-7034.

[6] Hrušková, V. (2010). Zhodnocení vybraných softwarových nástrojů určených pro modelování úniku nebezpečných látek při haváriích v chemickém průmyslu, in English: Evaluation of selected software tools for modeling leakage of hazardous substances in accidents in the chemical industry. Brno. Thesis. Vysoké učení technické v Brně (Technical University Brno). Head of thesis: doc. Ing. Vladimír Adamec, CSc.

[7] Kudlička, R. (2013). Postavení simulace a modelování v rámci záchranných a likvidačních prací, in English: Position of simulation and modeling in rescue and disposal work. Zlín. Thesis. Univerzita Tomáše Bati ve Zlíně (Tomas Bata University in Zlín). Head of thesis: Ing. Martin Hromada, Ph.D.

[8] Emergency Response Planning Guidelines (2017). Office of Response and Restoration [online]. [quoted on 201708-16]. Available at: https://response.restoration.noaa.gov/erpgs

[9] Parametrické testy - Studentův t-test, in English: Parametric tests - Student's t-test (2013). Veterinární a farmaceutická univerzita Brno - statistika a výpočetní technika, (Veterinary and Pharmaceutical University of Brno - Statistics and Computing). [online]. Brno [quoted on 2017-08-16]. Available at: https://cit.vfu.cz/statpotr/POTR/Teorie/Predn3/ttest.htm

[10] Blistanova, M. (2014). Data Preparation for Logistic Modeling of Flood Crisis Management. In: 24th DAAAM International Symposium on Intelligent Manufacturing and Automation, 2013. Vienna, 1529 - 1533. ISBN 18777058. 